\title{
An Analysis of Grade IV's Error on Whole Number based on Newman Procedure's Cognitive Style
}

\author{
Dessy Rizki Suryani ${ }^{1}$, Murni Sianturi ${ }^{3}$, Khumaeroh \\ Dwi Nur 'Aini' ${ }^{4}$ Etriana Meirista ${ }^{5}$ \\ Mathematics Education Department \\ Universitas Musamus \\ Merauke, Indonesia \\ 1drsuryani7@gmail.com, ${ }^{3}$ murni@ @unmus.ac.id, \\ khumaerohdwinuraini@gmail.com, 5 etriana@unmus.ac.id
}

\author{
Luluk Wahyu Nengsih ${ }^{2}$ \\ Postgraduate of Primary Education Department \\ Universitas Negeri Malang \\ Malang, Indonesia \\ ${ }^{2}$ lulukwahyunengsih25@gmail.com
}

\begin{abstract}
This research aims to describe students' errors based on the Newman procedure in solving narrative questions on whole number reviewed from cognitive style and its causing factors. This was a descriptive qualitative research with the students of fourth grade of SD Negeri 1 Merauke of 2017/2018 served as the subject of the research. The data collection techniques used were subjective tests, interviews and documentation. Data analysis was done by data reduction, data presentation, and conclusion drawing. Based on the results of the research, students with FD cognitive style made reading error, comprehension error, transformation error, process skill error and encoding error. While the FI student made a mistake in the form of process skill error and encoding error. The causes of errors experienced by students include confusion regarding the completion steps, lack of mastery of the material, limited time to work, and not being accustomed to writing the final answer or drawing conclusions.
\end{abstract}

Keywords - newman error; cognitive style; field dependent; field independent

\section{INTRODUCTION}

Mathematics is a compulsory subject that is taught at every level of education. However, there are still many students who think that learning mathematics is not interesting and boring. In addition, the number of formulas make mathematics is increasingly dislike by students. Abdurrahman reveals that many students assume that mathematics is the most difficult lesson compared to other subjects [1]. Subsequently, it became a stigma that developed among students to date.

Learning mathematics requires the student to both master the concept and its application in solving the problem. Mathematical problems are usually manifested in the form of narrative text so that several competencies are needed to find a solution. Competencies that must be possessed and mastered by students are competencies in verbal abilities and algorithmic abilities[2]. Verbal ability is the ability of students to understand existing problems and be able to interpret them into mathematical models. While the ability of algorithms is the ability to determine the right algorithm to be used in finding solutions, accuracy of calculations, and able to draw conclusions according to the purpose of the problem.
Based on observations on fourth grade students of SD Negeri 1 Merauke, it is known that there are still many errors in solving the problems of the narrative text. It causes the teacher should analyze the work done by their students in order to increase students' competencies in solving the problems. There are various ways to reveal students' mistakes, one of which is by analyzing errors [3]. The goal is that the teacher as a facilitator in learning can provide appropriate guidance to students' needs.

Various methods for analyzing student errors have been put forward by experts. One of the most widely used is error analysis based on the Newman procedure. Newman based error analysis is the most chosen because of having higher credibility. This opinion is in line with that stated by White that error analysis based on the Newman procedure has better credibility when compared to other types of error analysis[4]. The types of errors that students make, according to Newman, consist of five, namely reading errors, comprehension errors, transformation errors, process skills errors, and encoding error [4].

Many previous studies have been conducted related to the errors done by students were caused by internal factors. One of the influencing internal factors is the cognitive style. According to Coop and Sigel, cognitive style has a correlation to intellectual and perceptual behavior[5]. Intellectual behavior is related to an individual's ability to think, while perceptual behavior is related to an individual's perspective. This indicates that cognitive style influences students' ability to solve math problems. Thus, it can be concluded that cognitive style is a characteristic of a person in receiving, remembering, and processing information obtained to find solutions to solve problems.

The teacher as an educator needs to know the cognitive style possessed by each student. By knowing the cognitive style that students have in learning mathematics, teachers are able to fasilitate the students in overcoming their difficulties [6]. Therefore, it is important to be familiar with the types of cognitive styles of each student in order to analyze errors experienced by students in finding mathematical solutions. 
Witkin (1977) divides cognitive style into two types, namely field dependent and field independent [3]. Witkin further states that students with field depedent cognitive style tend to organize and process information received as a single unit and focus more on the general picture. The impact is the students become dependent because they only use information that has been known beforehand and requires motivation externally. However, students with field dependent cognitive styles are able to work together with others, because of their well-developed social orientation. While students with field independent cognitive style, according to Witkin and Goodenough, more viewed a unit as elements of the context [7]. Students with this cognitive style are able to find information outside existing content so that they tend to be more independent. In addition, it can distinguish an object from other objects around it and more analytically. Moreover, the motivation possessed by students with this type of cognitive style depends on internal motivation but is less able to cooperate with others since this type of students prefer to work individually.

Susanto states that individuals with field independent cognitive style type are more analytical and can choose stimuli based on existing situations [3]. This causes the individual's perception to be only affected by a small part when there is a change in the environment. Whereas individuals with a field dependent cognitive style will have difficulty distinguishing stimulus if faced with different situations, so that the perceptions possessed will be easily influenced by their surroundings. The difference of viewpoint due to cognitive style is not infrequently making students make mistakes when working on the problem. Errors made by students need to be analyzed in order to obtain a clear description of the weaknesses that students have in solving math problems [6].

Some previous studies reveal that cognitive style influences students' ability to solve problems. Research conducted by Ngilawajan concludes that students with independent field cognitive style were better at understanding problems than students with field dependent cognitive styles [8]. In addition, Akaramunnisa and Sulestery also state that field independent students with high initial abilities can understand and solve problems better and analytically than field dependent students [9].

Based on the above background, the purpose of this research is to analyze student errors based on the Newman procedure in solving narative question in the matter of chopped numbers in terms of cognitive style and the factors that cause errors.

\section{RESEARCH METHOD}

This research was conducted in SD Negeri 1 Merauke in the 2017/2018 academic year with the research subjects of six students of grade IV. This was a descriptive qualitative research which aimed to reveal the students' errors in solving the whole number problem in terms of cognitive style. In the first stage, test questions were given to determine the type of cognitive style that students have. This type of test was a group embedded figure test (GEFT) that has been developed by Witkin. Score results obtained from student answers were then grouped based on criteria as set by Gordon and Wyant (1994) where scores from 0 to 11 belong to the field dependent (FD) category while scores from 12 to 18 are included in the field independent (FI) category [10]. The next step was the provision of narrative questions related to the material of whole numbers for the six students who were selected as research subjects. Selected students represent each type of field dependent and field independent cognitive style. Whereas for the last step was by conducting an interview as a form of verification and confirmation of student answers.

The form of the questions given to students was: "Mr. Heru has 5 apple orchards. At the time of the harvest, the first orchard produced 3,543 apples and the second orchard produced 2,345 apples. The total apples from all Mr. Andi's gardens are 21,364 apples. How many apples are produced from the third, fourth and fifth gardens? " The following is an indicator of student errors based on the Newman procedure [11].

TABLE I. INDICATORS OF ERRORS ACCORDING TO NEWMAN

\begin{tabular}{|l|l|}
\hline \multicolumn{1}{|c|}{ Type of Error } & \multicolumn{1}{c|}{ Indicator } \\
\hline Reading Errors & $\begin{array}{l}\text { Error reading important words in the question. } \\
\text { Error reading main information. } \\
\text { - } \begin{array}{l}\text { Students do not use the information obtained in } \\
\text { solving problems }\end{array}\end{array}$ \\
\hline $\begin{array}{l}\text { Comprehension } \\
\text { Errors }\end{array}$ & $\bullet \begin{array}{l}\text { Students have not been able to capture the } \\
\text { information contained in the question correctly. }\end{array}$ \\
\hline $\begin{array}{l}\text { Transformation } \\
\text { Errors }\end{array}$ & $\bullet \begin{array}{l}\text { Students fail to convert information into correct } \\
\text { mathematical sentences. }\end{array}$ \\
\hline Process Skills Errors & $\bullet \begin{array}{l}\text { Students make mistakes in performing } \\
\text { calculations. }\end{array}$ \\
\hline Encoding Error & $\bullet \begin{array}{l}\text { Students cannot write the final answer or make } \\
\text { conclusions. }\end{array}$ \\
\hline
\end{tabular}

In this research, the data analysis technique consisted of three stages, namely 1) the data reduction stage where the activity of examining and reviewing the GEFT test results, subjective tests, and the results of the interviews were conducted. The results of the interview are transcribed so that data that is not needed will be discarded. 2) The second stage was that the data presented neatly and organized. 3) The final stage was drawing conclusions. This activity was carried out by comparing the subject statement with the meaning contained in the previous research statement.

\section{FINDINGS AND DISCUSSION}

Based on the results of the GEFT test, it was found that students who had a field dependent cognitive style were 4 people. While students with field independent cognitive style were 2 people. Following are the results and discussion for each cognitive style.

\section{A. Field Dependent Cognitive Style (FD)}

Students with FD cognitive style are given codes S1, S2, S3, and S4. 


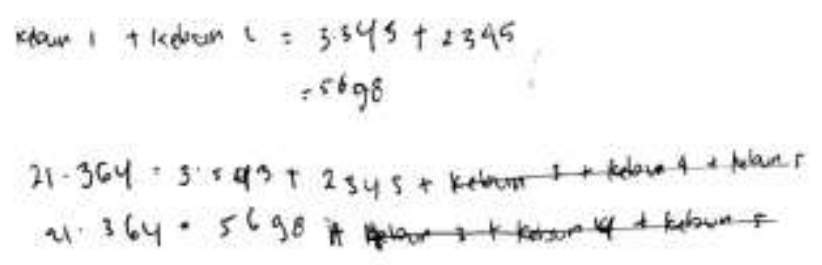

Fig. 1. S1's answer sheet

The figure shows that the student did not write what is known and asked. S1 is not able to write down the number of harvests of both apple orchards that are known. S1 failed in determining the calculation and does not write conclusions. This means that $\mathrm{S} 1$ makes reading errors, comprehension error, transformation errors, process skill error, and encoding error. Based on the results of the interview, it is known that the factor that caused the error to occur was because S1 was confused to determine the completion step.

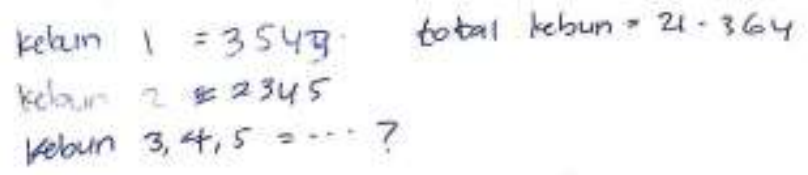

Fig. 2. S2's answer sheet

The figure shows that S2 only wrote what is known and asked. This means that the S2 experienced all errors except errors in reading and understanding the problem. In addition, the results of the interviews showed that S2 made transformation error, process skill error, and encoding error were caused by a lack of understanding of the questions and mastery of the material.

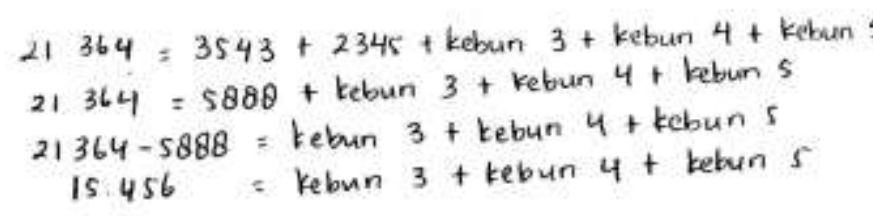

Fig. 3. S3's answer sheet

The figure shows that the S3 immediately worked on the problem without writing down what was known and asked. But, S3 could not write the final answer and conclusion because it hasn't finished working on it. This means that S3 did not use the correct steps in the work so that it has a reading error. As a result, S3 has experienced reading errors, comprehension error, transformation errors, process skill errors, and encoding error.
S3's interview results indicate that $\mathrm{S} 3$ has experienced comprehension error, transformation errors, and encoding error. This is due to $\mathrm{S} 3$ felt that the time had running out.

$$
\text { Kebun } 1=3543
$$

Fig. 4. S4's answer sheet

The figure shows that S4 did not work on the given problem so that $\mathrm{S} 4$ is attributed all the errors. The results of the interview suggest that $\mathrm{S} 4$ could not comprehend the text so that it could not work on it. Moreover, S4 had also running out of time.

\section{B. Field Independent Cognitive Style (FI)}

Students with FI cognitive style are given the code S5 dan S6.

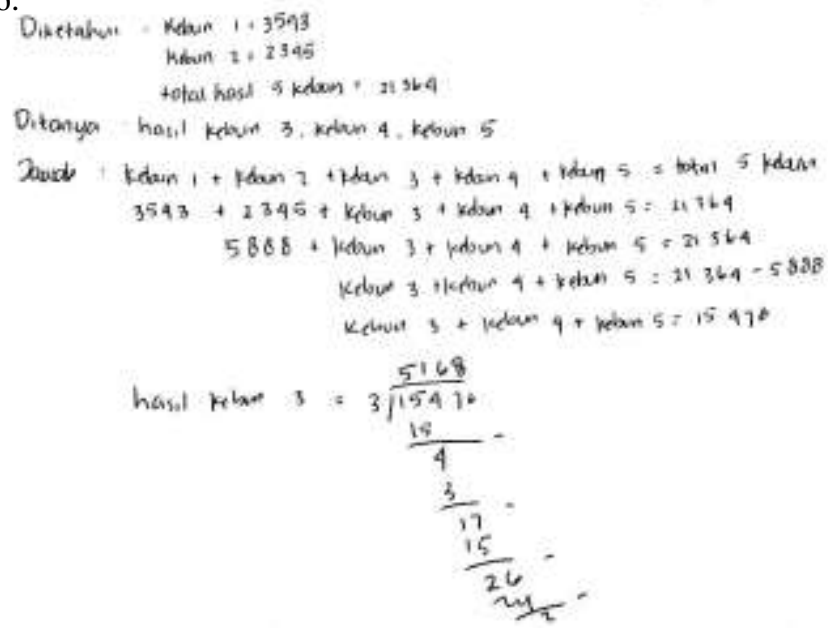

Fig. 5. S5's answer sheet

The figure shows that S5 was able to comprehend the problem as shown by correctly written formula even though it still not able to properly finish the calculation of the fourth and fifth garden. Moreover, S5 was also failed to write down the conclusion which indicates that S5 experienced process skill error and encoding error. The interview suggests that the errors are caused due to lack of accuracy and lack of time.

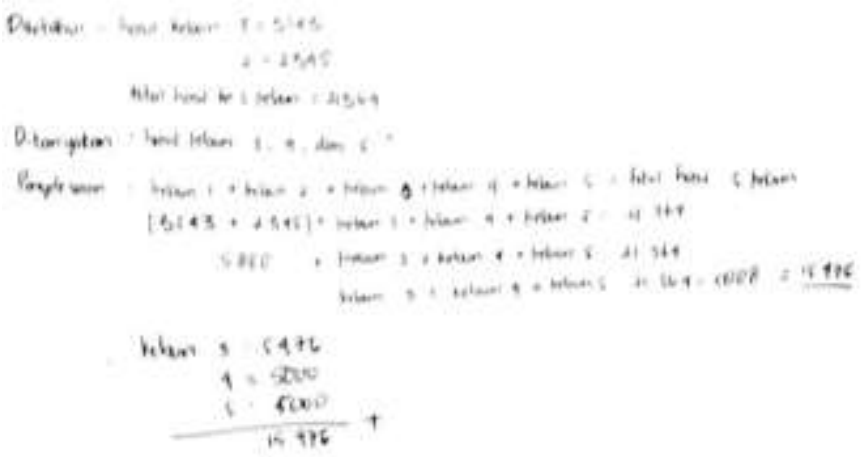

Fig. 6. S6's answer sheet 
The figure shows that S6 was able to comprehend the problem and wrote the applied formula as well as conducting correct calculation process. However, S6 was not able to write the conclusion which means that S6 experienced encoding error. The interview suggests that the S6 forgot to write the conclusion since it has not accustomed to it.

\section{CONCLUSION AND SUGGESTION}

Based on the results of the analysis and interviews carried out related to student errors based on the Newman procedure in terms of cognitive style, it can be concluded as follows: 1) students with field dependent cognitive style tend to make reading errors, comprehension error, transformation error, process skill error, and encoding error. In line with the results of Zamzam's research, errors are often carried out at the stage of transformation and process skills [12]. Whereas students with field independent cognitive style make the process skill errors and encoding error. 2) The causes of errors made by students are the confusion related to completion steps, lack of mastery of material, limited time to work, and not accustomed to writing the final answers and conclusions.

The limitations of this research are only focused on the errors of grade IV students with field dependent and field independent cognitive styles with the whole number based on the Newman procedure. Therefore, it is expected that further research can be carried out on student errors based on field dependent and field independent cognitive styles with different material as well as with other error analysis procedures.

\section{ACKNOWLEDGMENT}

We thank Universitas Musamus for facilities, supports, and publications.

\section{REFERENCES}

[1] M. Abdurrahman, Anak Berkesulitan Belajar: Teori, Diagnosis, dan Remedial. Jakarta: Rineka Cipta, 2012.

[2] Hartini, "Analisis kesalahan siswa menyelesaikan soal cerita pada kompetensi dasar menemukan sifat dan menghitung besaran-besaran segi empat siswa kelas VII semester II SMP It Nur Hidayah Surakarta tahun pelajaran 2006 / 2007," Universitas Sebelas Maret, Surakarta, 2008.

[3] D. Herry, A. Susanto, and M. Pd, "Mahasiswa Field Independent dan Field Dependent Dalam Memahami Konsep Grup *," in Semnas Matematika dan Pendidikan Matematika, 2008.

[4] A. L. White, "Numeracy, Literacy and Newman's Error Analysis," Allan Leslie White J. Sci. Math. Educ. Southeast Asia, vol. 33, no. 2, pp. 129 148, 2010.

[5] S. R. Amalia, "Analisis Kesalahan Berdasarkan Prosedur Newman Dalam Menyelesaikan Soal Cerita Ditinjau Dari Gaya Kognitif Mahasiswa," Aksioma, vol. 8, no. 1, pp. 17-30, 2017.

[6] F. A. Nurussafa'at, I. Sujadi, and Riyadi, "Analisis Kesalahan Siswa Dalam Menyelesaikan Soal Cerita Pada Materi Volume Prisma Dengan Fong'S Shcematic Model For Error Analysis Ditinjau dari Gaya Kognitif Siswa (Studi Kasus Siswa Kelas VIII Semester II SMPIT Ibnu Abbas Klaten Tahun Ajaran 2013 /2014,” J. Elektron. Pembelajaran Mat., vol. 4, no. 2, pp. 174-187, 2016.

[7] A. Altun and M. Cakan, "Undergraduate Students ' Academic Achievement, Field Dependent / Independent Cognitive Styles and Attitude toward Computers," Educ. Technol. Soc., vol. 9, no. May, pp. 289-297, 2006.

[8] D. A. Ngilawajan, "Proses Berpikir Siswa SMA Dalam Memecahkan Masalah Matematika Materi Turunan Ditinjau dari Gaya Kognitif Field Independent Dan Field Dependent," Pedagogia, vol. 2, no. 1, pp. 71-83, 2013.

[9] Akramunnisa and A. I. Sulestry, "Analisis Kemampuan Menyelesaikan Masalah Matematika Ditinjau Dari Kemampuan Awal Tinggi Dan Gaya Kognitif Field Independent ( Fi )," Pedagog. J. Pendidik. Mat., vol. 1, pp. 46-56, 2016.

[10] D. R. Puspananda and P. Suriyah, "Analisis Faktor pada Group Embbeded Figures Test untuk Mengukur Gaya Kognitif,” pp. 225-230, 2017.

[11] S. Amini, T. Nova, H. Yunianta, U. Kristen, and S. Wacana, "Analisis Kesalahan Newman Dalam Menyelesaikan Soal Cerita Aritmatika Sosial Dan Scaffolding -Nya," 2018.

[12] K. F. Zamzam and F. A. Patricia, "Error Analysis of Newman to Solve the Geometry Problem in Terms of Cognitive Style," vol. 160, no. Incomed 2017, pp. 24-27, 2018. 